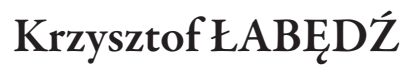

Akademia Ignatianum w Krakowie

kswan@up.krakow.pl

\title{
PROBLEMY ZWIĄZANE Z BADANIEM OPOZYCJI POLITYCZNEJ (PRZYPADEK POLSKI)
}

ABSTRACT Problems associated with analysing political opposition (based on Poland) Studies on political opposition in the contemporary Poland present a range of difficulties and require making a lot of decisions. They are connected, among other things, with defining political opposition and determining designates that fall within the range of this definition, specifying conditions and measures that enable individual political groups to be classified to its various types (mainly the conditions concerning distinguishing anti-system opposition) and primarily determining the manner of 'measuring' the resistance degree assuming that 'resistance' is a variable that can assume various values. It is also significant to specify the degree of integrity (normative consensus and structural integrity) of opposition, i.e. the factor that influences its power of action. This paper presents these problems together with certain methods of solving them used in the studies conducted. It was concluded that studies in the subject of opposition require various methods and different research perspectives, including behaviourism and interpretationism.

Key words: political opposition, research of opposition, definition of opposition, types of opposition

Słowa kluczowe: opozycja polityczna, badanie opozycji, definicja opozycji, typy opozycji 


\section{WPROWADZENIE}

Problematyka opozycji politycznej nie jest zbyt często przedmiotem odrębnych zainteresowań i badań, mimo że opozycja jest elementem każdego względnie trwałego systemu, w którym istnieje władza polityczna ${ }^{1}$. W dodatku nawet jeśli poszczególni autorzy podejmują te zagadnienia, to w większości jest to opis wydarzeń z udziałem opozycji (narracja historyczna) lub określenie jej statusu normatywnego, bez próby zdefiniowania, czym jest opozycja polityczna, oraz opracowania jakiegoś metodologicznego schematu umożliwiającego badanie opozycji ${ }^{2}$, najlepiej w ujęciu komparatystycznym.

Zasadniczym celem tego tekstu jest zasygnalizowanie niektórych trudności, jakie napotyka się podczas badania opozycji politycznej w Polsce. Zarysowane zostaną także pewne możliwe sposoby rozwiązywania występujących problemów, choć efektem tych rozważań będzie przede wszystkim stwierdzenie, że niemożliwe jest przyjęcie jakiegoś jednolitego modelu w tym zakresie, wiele zależy od czynników sytuacyjnych, a szereg podziałów i rozróżnień jest nieostrych.

Przedstawiane problemy odnoszą się przede wszystkim do sytuacji we współczesnej Polsce, czyli do funkcjonowania opozycji politycznej w warunkach systemu demokratycznego o charakterze parlamentarno-gabinetowym. W związku z tym pominięte zostaną m.in. liczne specyficzne problemy dotyczące badania opozycji w systemach niedemokratycznych ${ }^{3}$. Nie wdając się w szersze rozważania na temat roli opozycji w systemie demokratycznym, przytoczę jedynie słowa Guglielma Ferrera: $W$ demokracjach opozycja jest nie mniej od rzadu ważnym organem suwerenności ludu. Ttumienie opozycji to ttumienie suwerenności ludu ${ }^{4}$. Ranga przedmiotu wskazuje, że także sposoby i procedury badania opozycji politycznej powinny być przedmiotem uwagi, a wypracowane rozwiązania powinny gwarantować systematyczny i rzetelny opis zjawiska.

Dla osiągnięcia tego warto zastanowić się m.in. nad takimi kwestiami, jak: sposób definiowania opozycji politycznej i określenie desygnatów mieszczących się w zakresie tego pojęcia, określenie warunków i miar umożliwiających zaliczenie poszczególnych ugrupowań opozycji do różnych jej typów (głównie chodzi o warunki wyróżnienia opozycji o charakterze antysystemowym), a przede wszystkim sposób „zmierzenia” stopnia opozycyjności, zakładając, że „opozycyjność” jest zmienną mogącą przyjmować różne wartości. Można dodać, że niekiedy granica pomiędzy tym, co jest opozycją,

1 K. Pałecki, Opozycja polityczna - próba typologii, [w:] Opozycja w systemach demokratycznych i niedemokratycznych, red. K. Łabędź, M. Mikołajczyk, Kraków 2001. Oczywiście od wspomnianej reguły są wyjątki, chociażby w postaci niżej cytowanych książek Zbigniewa Machelskiego, Stanisława Bożyka czy pod redakcją Eugeniusza Zwierzchowskiego.

2 Próbę tego rodzaju badań można znaleźć w: Wybrane aspekty funkcjonowania Sejmu w latach 1997-2007, red. J. Sokołowski, P. Poznański, Kraków 2008.

3 Pisałem na ten temat w innych miejscach, zob. np. K. Łabędź, Znaczenie pojęcia „opozycja polityczna” w odniesieniu do Polski lat osiemdziesiatych, [w:] Historia, polityka, spoteczeństwo. Ksiega jubileuszowa dedykowana Profesorowi Henrykowi Cimkowi, red. W. Bonusiak i in., Rzeszów 2008.

4 G. Sartori, Teoria demokracji, przeł. P. Amsterdamski, D. Grinberg, Warszawa 1998, s. 50. 
a tym, co nią nie jest, jest płynna i może ulegać zatarciu. Istotnym problemem wydaje się też badanie stopnia integracji (konsensusu normatywnego i integracji strukturalnej) opozycji, czyli czynnika wpływającego na siłę jej oddziaływania, a także innych czynników o podobnym oddziaływaniu; wiążą się z tym kolejne trudności.

\section{MOŻLIWOŚCI DEFINIOWANIA OPOZYCJI POLITYCZNEJ}

Przechodząc do określenia, czym jest opozycja - wiedząc, że termin ten może oznaczać określonego rodzaju postawy, zachowania oraz zorganizowane formy działania zbiorowego - z założenia rozważania ograniczymy do badania opozycji w ostatnim z wymienionych znaczeń. Problem istnienia różnych możliwości definiowania opozycji rozumianej jako zorganizowana forma działania $\mathrm{w}$ przypadku systemu demokratycznego pozornie nie jest bardzo złożony, gdyż można zastosować zarówno definicje o węższym charakterze (w myśl których opozycja polityczna jest instytucją systemu demokracji parlamentarnej, stanowiącą alternatywę polityczną i programową dla ugrupowania rządzącego ${ }^{5}$ ), jak i mające szerszy zakres, co pozwala mówić o opozycji politycznej również w systemach niedemokratycznych (opozycja polityczna obejmuje także partie, ruchy i organizacje odrzucające istniejący system polityczny, prezentujące się jednak jako alternatywa wobec istniejących władz, jak np. opozycja nielojalna u Juana J. Linza ${ }^{6}$ ).

Pozostaje jednak kwestia dokonania wyboru definicji zastosowanej w badaniach. W węższym ujęciu opozycję można rozumieć jako spójną, regularnie i wspólnie działająca grupę, która jest w stanie przedstawić się wyborcom jako alternatywny rząd z alternatywną polityką ${ }^{7}$. W podobnym kierunku zmierza określenie opozycji sensu stricto Tomasza Krawczyka, mówiącego o formalnych organizacjach politycznych, dążących do przejęcia władzy państwowej lub zmiany reżimu politycznego ${ }^{8}$, a także rozważania Stanisława Bożyka, który termin „opozycja” odnosi do partii i ugrupowań politycznych dążących do przejęcia władzy9. Przyjęcie takiego rozwiązania ogranicza opozycję do pewnych partii i ugrupowań politycznych, które nie uczestniczq w sprawowaniu rzadów, lecz zajmują krytyczna postawe wobec rządzacej koalicji (partii politycznej) i realizowanej przez nia polityki oraz dąża do przejęcia wtadzy w państwie, wykorzystując $w$ tym celu zarówno zagwarantowane konstytucyjnie i ustawowo, jak też inne, ale mieszczace się $w$ ramach obowiazujacego prawa, formy rywalizacji politycznej, z zamiarem dokonania

5 Por. Z. Machelski, Opozycja w systemie demokracji parlamentarnej. Wielka Brytania, Niemcy, Wtochy, Warszawa 2001, s. 9-12; zob. też Political Oppositions in Western Democracies, red. R.A. Dahl, New Haven 1966, s. xvi-xvii.

6 J.J. Linz, Kryzys, zatamanie i powrót do równowagi, [w:] Wtadza i spoteczeństwo 2. Antologia tekstów z zakresu socjologii polityki, wybór i oprac. J. Szczupaczyński, Warszawa 1998, s. 41-42.

A Dictionary of the Social Sciences, red. J. Gould, W.I. Kolb, New York 1964, s. 478.

8 T. Krawczyk, Opozycja polityczna w państwach demokratycznych, [w:] Studia z teorii polityki, t. 3, red. A. Czajowski, L. Sobkowiak, Wrocław 2000, s. 132.

$9 \quad$ S. Bożyk, Prawnoustrojowy status opozycji parlamentarnej w Sejmie Rzeczypospolitej Polskiej, Białystok 2006, s. 20. 
określonych reform ustrojowych lub zmiany istniejacego systemu politycznego i spoteczno-gospodarczego ${ }^{10}$.

Choć stwierdzono, że współczesne definicje opozycji umiejscawiają ją w parlamencie $^{11}$, wydaje się, że większe możliwości odtworzenia i scharakteryzowania działalności opozycyjnej oraz jej zróżnicowania wiążą się z przyjęciem definicji możliwie szerokiej, np. takiej, jaką formułuje Ryszard Herbut. Zgodnie z nią opozycja polityczna to ugrupowania polityczne, w tym również i partie polityczne, które w mniej lub bardziej zorganizowany sposób, wykorzystując zarówno konstytucyjnie dopuszczalne, jak i niekonwencjonalne (pozakonstytucyjne) metody prowadzenia rywalizacji politycznej, dąza do przejecia lub zmiany wtadzy państwowej ${ }^{12}$. Takie ujęcie daje bowiem możliwość obserwowania procesu tworzenia i działania szerokiego ruchu społecznego dążącego do zmiany rządu, którego zadaniem jest wsparcie partii opozycyjnych. W praktyce zatem rodzi się problem, jakie konkretnie ugrupowania, jako mieszczące się w zakresie opozycji, należy uwzględnić w badaniach.

\section{MOŻLIWY ZAKRES POJĘCIA OPOZYCJI POLITYCZNEJ}

Przyjęcie takiej definicji implikuje pytania m.in. o to, które ugrupowania, oprócz określających się jako partie polityczne, należy zaliczyć do opozycji politycznej, oraz czy warto zaliczać do opozycji wszystkie partie polityczne spełniające wymienione warunki. Kwestia pierwsza dotyczy przede wszystkim niektórych ruchów i organizacji społecznych, druga - sposobu interpretacji słowa „dąży”. Zacznijmy jednak od sprawy zaliczania partii politycznych do opozycji politycznej traktowanej jako przedmiot badań. Co prawda, zarejestrowanie jakiegoś ugrupowania jako partii politycznej z definicji oznacza jego deklarację udziału w walce o władzę, jednak w praktyce kwestia ta nie jest jasna.

W Polsce zarejestrowanych jest 85 partii politycznych (stan na 25 listopada 2016) ${ }^{13}$, jednak mają one bardzo zróżnicowane znaczenie, a część z nich w ogóle nie podejmuje żadnej działalności (ok. 20\%). Tę ostatnią kategorię można zatem pominąć, badając opozycję, ale mimo to pozostaje kilkadziesiąt partii, niektóre obecne wyłącznie w Internecie (oczywiście chodzi o te, które ujawniają postawy opozycyjne wobec rządu). W przypadku partii obecnych w parlamencie ich zaliczenie do opozycji nie nastręcza większych trudności, oprócz odpowiedzi na pytanie, czy wszystkie ugrupowania, które

10 Tamże.

11 Z. Machelski, Opozycja w systemie..., s. 15.

12 Opozycja polityczna, [w:] Leksykon politologii, red. A. Antoszewski, R. Herbut, Wrocław 1995, s. 24; tak samo w: Opozycja polityczna, [w:] Encyklopedia politologii, t. 1: Teoria polityki, red. W. Sokół, M. Żmigrodzki, Kraków 1999. Podobnie definiuje opozycję także T. Krawczyk w cytowanym wyżej tekście.

13 Wykaz partii wpisanych do ewidencji partii politycznych, PKW, [online] http://pkw.gov.pl/322_Wykaz_partii_politycznych/1/404_WYKAZ_PARTII_WPISANYCH_DO_EWIDENCJI_PARTII_POLITYCZNYCH, 25 XI 2016. 
nie uczestniczą w tworzeniu rządu lub nie popierają rządu, należy zaliczyć do opozycji. Punktem wyjścia do udzielenia odpowiedzi może być określenie Eugeniusza Zwierzchowskiego, w myśl którego przez opozycję parlamentarna rozumiemy grupy polityczne lub frakcje parlamentarne, które z jakichkolwiek względów nie uczestniczac w tworzeniu rządu, odnosza się krytycznie do jego politycznego programu i dziatalności oraz ksztattują wtasna alternatywe programowa i personalna, by w ramach konstytucyjnie ustalonych regut przejać i sprawować rządy ${ }^{14}$. Przyjmując takie określenie, można stwierdzić, że poza zakresem pojęcia opozycji parlamentarnej pozostają ugrupowania kwestionujące zasady systemu sprawowania władzy - opozycja antysystemowa - a więc część opozycji zasiadającej w parlamencie może nie należeć do „opozycji parlamentarnej”, ale będzie należeć do opozycji politycznej; podobnie w przypadku ugrupowań, które nie wchodzac w sktad obozu rządowego, zachowuja wobec niego stanowisko neutralne lub niejasne bądź wyczekujace, wyrażające się między innymi powstrzymywaniem się od udziatu w gtosowaniach itp. ${ }^{15}$

Wydaje się, że na zakres „opozycji parlamentarnej” można spojrzeć także w szerszy sposób, który uwzględniłby więcej różnych odcieni i sposobów prowadzenia działań opozycyjnych. Należy przy tym odwołać się np. do określenia opozycji parlamentarnej rozumianej jako stowarzyszenie deputowanych, którzy oficjalnie nie deklaruja poparcia wobec istniejacego rzadu ${ }^{16}$. Wynika z tego, że kryterium zaliczania do opozycji nie jest zajmowanie wyraźnie krytycznego stanowiska wobec rządu, ale wystarczy brak deklaracji jego poparcia. Problemem pozostaje natomiast sposób traktowania tych ugrupowań (lub poszczególnych posłów), które tworząc rząd, wciąż kwestionują jego posunięcia, co wyrażać się może głosowaniem przeciwko projektom rządowym (z taką sytuacją mieliśmy do czynienia m.in. w okresie rządów AWS). Uwzględniając taką możliwość, warto, oprócz opozycji parlamentarnej i jednocześnie politycznej, używać kategorii „zachowania opozycyjne”.

W odniesieniu do opozycji pozaparlamentarnej problem jest bardziej złożony, gdyż dotyczy partii, które w większości należą do kategorii określanej niekiedy jako „plankton polityczny" ${ }^{17}$. Pewnym przybliżeniem do jego rozwiązania może być następujące zdanie Stanisława Bożyka: Do opozycji pozaparlamentarnej zalicza się najcześciej te partie polityczne, które zgtaszaja swoich kandydatów w wyborach parlamentarnych, lecz

14 Opozycja parlamentarna, red. E. Zwierzchowski, Warszawa 2000, s. 11.

15 Tamże.

16 Autorką tego określenia jest Sylvie Giulj. Zob. T. Krawczyk, Opozycja polityczna..., s. 141.

17 Określenie to przeznaczone jest dla partii politycznych o niewielkim znaczeniu. Określenie to ma charakter ironiczny czy wręcz pogardliwy. W ramach "planktonu” więsszośćstanowia partie, dla których sukcesem jest rejestracja w ewidencji partii politycznych, a tylko nieliczne uzyskuja mandaty parlamentarne (najczęściej dzięki startom z list większych ugrupowań). Zjawisko to jest dość szerokie - w ewidencji partii od momentu jej utworzenia zarejestrowanych byto bowiem ponad 300 ugrupowań, podczas gdy większość mandatów poselskich przypada zaledwie kilku największym z nich - Plankton polityczny, Wikipedia, [online] https://pl.wikipedia.org/wiki/Plankton_polityczny. Pod tą nazwą istnieje strona internetowa poświęcona właśnie małym partiom - „blog o polityce i małych partiach politycznych”: PLANKTON POLITYCZNY - Blogpolityczny o planktonie politycznym, [online] planktonpolityczny.blox.pl, 25 XI 2016. 
wskutek niewielkiego poparcia ze strony wyborców bądź też w wyniku stosowania niekorzystnego dla matych ugrupowań politycznych systemu ustalania wyników wyborów [...], przejściowo lub trwale nie posiadaja wtasnej reprezentacji w parlamencie ${ }^{18}$. Można z tego wnosić, że do opozycji politycznej na pewno zaliczymy te ugrupowania, które brały udział w wyborach, tworząc czy współtworząc komitety wyborcze, oraz że trwały brak reprezentacji parlamentarnej nie jest powodem niezaliczenia do opozycji. Wydaje się również, że partie nieuczestniczące w wyborach (niewystawiające własnych kandydatów), jako nieprzejawiające aktywności na zasadniczej dla partii płaszczyźnie (taką partią jest np. Unia Polskich Ugrupowań Monarchistycznych), nie powinny być zaliczane do opozycji. Ewentualnym wyjątkiem mogą być partie kontestujące w ten sposób system demokratyczny, aktywnie działające na innych płaszczyznach (z wyłączeniem partii opowiadających się za rozwiązaniami siłowymi ${ }^{19}$ ). Otwarte natomiast pozostaje pytanie, czy do opozycji zaliczać te partie, które bezskutecznie wystawiły swoich kandydatów poprzez listy innych ugrupowań (najczęściej na miejscach z założenia uniemożliwiających wejście do parlamentu). Za odpowiedzią twierdzącą mógłby przemawiać fakt posiadania przez te ugrupowania przedstawicieli w strukturach władzy lokalnej.

Przechodząc do ugrupowań niebędących partiami - w Polsce, ze względu na wydarzenia z niedawnej przeszłości, dość oczywiste jest stwierdzenie, że istotną rolę polityczną (w walce o władzę i w rządzeniu państwem) mogą odgrywać związki zawodowe, które zatem mogą być także częścią opozycji politycznej. Zdanie to znajduje potwierdzenie np. w fakcie organizacji przez trzy największe centrale związkowe we wrześniu 2013 r. protestów i manifestacji, podczas których zasadniczym żądaniem była zmiana rządu.

Inny rodzaj ugrupowań, które należałoby uwzględniać, to różnego typu ruchy społeczne, często przyjmujące status stowarzyszeń. Kluby Gazety Polskiej, Solidarni 2010, Ruch Społeczny im. Prezydenta Rzeczypospolitej Polskiej Lecha Kaczyńskiego, Obywatelskie Kluby Akademickie im. Prezydenta Lecha Kaczyńskiego, działające w Poznaniu, Warszawie, Krakowie, Łodzi, Niepokonani 2012, Oburzeni - to tylko niektóre z nich, w większości powiązane z Prawem i Sprawiedliwością. Łączyło je dążenie do odebrania władzy koalicji PO-PSL oraz w części charakterystyczne dla środowisk pisowskich sugestie zdrady okrągłostołowej, zamachu smoleńskiego i fałszowania wyborów. W maju 2014 r. na spotkaniu stowarzyszeń „walczących z patologiami” będącymi wynikiem „okrągłego stolca 1989” powołano Porozumienie Organizacji Patriotycznych i Solidarnościowych ${ }^{20}$. W lipcu tegoż roku Ruch Oburzonych informował, że prawie wszystkie organizacje ogólnopolskiego Ruchu Oburzonych przystąpiły do Porozumienia Organizacji Patriotycznych i Solidarnościowych, którego celem jest budowa wspólnego komitetu wyborczego w wyborach samorządowych z możliwościa kontynuowania wspótpracy w wyborach do Sejmu ${ }^{21}$. Sformułowano w ten sposób zadanie charak-

$18 \quad$ S. Bożyk, Prawnoustrojowy status..., s. 24.

19 Tamże, s. 18.

20 Porozumienie-organizacji, [online] pressmix.eu, 21 VII 2014.

21 Oświadczenie Grupy Uderzeniowej, [online] www.oburzeni.org.pl, 25 XI 2016. 
terystyczne dla partii politycznych. W kadencji parlamentu rozpoczętej wyborami w 2015 r. najsilniejszą organizacją opozycyjną jest Komitet Obrony Demokracji, występujący często w różnego rodzaju manifestacjach i innych przedsięwzięciach razem z partiami opozycyjnymi - Nowoczesną i PO. W jednym z komentarzy stwierdzono w związku z tym: Komitet Obrony Demokracji z kolei nieuchronnie ewoluuje w przyszta partię polityczna. Liderzy KOD czują się bez mata spadkobiercami aktywistów „Solidarności" z roku 1980, staraja się rekonstruować tamte emocje, powoli się ucza nimi zarzq$d z a c^{22}$. Przykładem działań o charakterze opozycyjnym podejmowanych przez KOD może być happening zorganizowany w październiku 2016 r. na Błoniach w Krakowie, podczas którego kilka tysięcy osób ułożyło widoczny z góry napis „Mamy dość”.

Ruchem społecznym popieranym przez część ugrupowań prawicowych, wykorzystywanym do walki z rządem PO-PSL, a obecnie z opozycją (przede wszystkim chyba ze względu na metody działania wykraczające poza ramy demokratycznego systemu politycznego) jest ruch kibicowski. W ocenie Rafała Chwedoruka środowiska związane z Prawem i Sprawiedliwościa flirtuja z kibolami i daja im przepustkę do gtównego nurtu zycia spoteczno-politycznego, ponieważ prawicowy elektorat i pseudokibiców potaczyto silne w obu tych grupach poczucie stygmatyzacji $i$ wykluczenia przez rzadzacych $i$ mainstreamowe media ${ }^{23}$. Aktualnie ruch kibicowski składa obietnice zawarte w tytule jednej z wypowiedzi: „Dla Was nie będzie gwizdów, będą szubienice”. Kibole Legii Warszawa zapowiadaja wymordowanie KOD, opozycji i mediów ${ }^{24}$.

Nie kontynuując tej wyliczanki ugrupowań, które można zaliczać do opozycji politycznej, należy zadać pytanie, które z tego rodzaju ugrupowań (przy założeniu przyjęcia szerszej definicji opozycji politycznej) do opozycji zaliczać. W ten sposób dochodzimy do zasadniczych problemów, a mianowicie: jakie są wskaźniki opozycyjności, z jakim natężeniem powinny występować, jak je mierzyć, co zrobić w sytuacji, gdy zachowania poszczególnych podmiotów są niespójne.

\section{WSKAŹNIKI OPOZYCYJNOŚCI I MOŻLIWOŚCI ICH POMIARU}

Jedno z podstawowych rozstrzygnięć musi dotyczyć tego, czy wybieramy jedną zmienną, która w najlepszy sposób charakteryzowałaby opozycję, czy konstruujemy syntetyczny wskaźnik w oparciu o wartości kilku zmiennych, czy też uwzględniamy kilka

22 W. Głowacki, Opozycja, o której marzy każdy rzad. KOD, PO i Nowoczesna mobilizuja już zmobilizowanych, „Dziennik Polska” 2016, 6 V, [online] http://www.polskatimes.pl/fakty/polityka/a/ opozycja-o-ktorej-marzy-kazdy-rzad-kod-po-i-nowoczesna-mobilizuja-juz-zmobilizowanych-analiza,9960410/, 27 XI 2016.

23 „Bunt stadionów” zachęta, by rząd Donalda Tuska obalili kibole? Politolog: Sam sobie zgotowat ten los, naTemat, 23 IV 2013, [online] http://natemat.pl/59423, bunt-stadionow-zacheta-by-rzad-donalda-tuska-obalili-kibole-politolog-sam-sobie-zgotowal-ten-los, 5 VI 2016.

24 „Dla Was nie będzie gwizdów, będa szubienice”. Kibole Legii Warszawa zapowiadaja wymordowanie KOD, opozycji i mediów, naTemat, 8 V 2016, [online] http://natemat.pl/179271, dla-was-nie-bedzie-gwizdow-beda-szubienice-kibole-legii-warszawa-zapowiadaja-wymordowanie-kod-opozycji-i-mediow, 27 XI 2016. 
zmiennych niezależnie od siebie. Jest to również pytanie o możliwość zastosowania pomiaru w jakiejś nieskomplikowanej formie. Rozwiązanie pierwsze jest najprostsze i przy jego zastosowaniu możemy uszeregować poszczególne ugrupowania ze względu na poziom ich opozycyjności. Jednak trudno odpowiedzieć na pytanie, jaka to powinna być zmienna, a przede wszystkim jak dokonać pomiaru. W odniesieniu do opozycji parlamentarnej może to być sposób zachowania podczas głosowań (o tym poniżej), ale co wziąć pod uwagę w przypadku ugrupowań pozaparlamentarnych? Być może zakres proponowanych zmian, a może poziom radykalizmu wypowiedzi albo częstotliwość organizowania czy uczestnictwa w wystąpieniach antyrządowych. Drugie rozwiązanie polegałoby ma połączeniu tych (a może także innych) wskaźników, ale tutaj problemem pozostaje pytanie, czy są one sobie równoważne i czy można przypisać im tę samą wartość liczbową (czy ewentualnie wartości ważone). Rozwiązanie trzecie prowadzi wyłącznie do opisu różnych aspektów i przejawów działalności ugrupowań opozycyjnych, a choć w ten sposób można dokładniej i pełniej je scharakteryzować, nie daje to możliwości skonstruowania jakiejś skali.

W przypadku opozycji parlamentarnej problem znowu wydaje się łatwiejszy do rozwiązania. Mamy bowiem możliwość zastosowania pewnych wskaźników mierzalnych, z których najprostszym i chyba najistotniejszym jest sposób głosowania poszczególnych ugrupowań w Sejmie. Można zatem policzyć przypadki głosowania ugrupowań opozycyjnych w taki sam sposób, jak głosują ugrupowania (ugrupowanie) tworzące rząd, oraz przypadki głosowania ugrupowań opozycyjnych przeciwko projektom rządu i złożonym przez posłów ugrupowania rządzącego (ugrupowań rządzących) (również przypadki wstrzymania się od głosu czy niewzięcia udziału w głosowaniu).

Wiąże się z tym jednak zasadnicza trudność, a mianowicie poszczególne głosowania nie są sobie równoważne przynajmniej z dwóch powodów: po pierwsze, dotyczą problemów o różnej wadze i znaczeniu, po drugie, w części przypadków sposób głosowania wynika ze zbieżności programów ugrupowań rządzących i opozycyjnych. Dochodzą do tego przypadki różnego rodzaju głosowań taktycznych. Pozostaje zatem albo zastosować taki wskaźnik, pamiętając o tym, że przynosi on uproszczone wyniki, albo podjąć się dość karkołomnego zadania analizy każdego projektu podlegającego głosowaniu, co praktycznie przekracza możliwości pojedynczych badaczy.

Zastosowanie omawianego tu sposobu postępowania pociąga za sobą także inne problemy, z których najistotniejszy to dość często występujący fakt niejednolitego głosowania posłów poszczególnych ugrupowań. Czasem dotyczy to pojedynczych osób, a czasem większej grupy. W tym zakresie konieczne jest przyjęcie kolejnego założenia upraszczającego - w przeprowadzonych badaniach przyjęto m.in., że do zaliczenia do określonego sposobu głosowania będzie brane pod uwagę głosowanie większości posłów danego ugrupowania, a sytuacja, w której nie więcej niż dziesięciu posłów głosowało przeciw lub wstrzymało się od głosu w głosowaniu dotyczącym projektów rządowych (i złożonych przez posłów ugrupowania rządzącego (ugrupowań rządzących), uznawana będzie za głosowanie jednogłośne. Uzasadnieniem takiego postępowania, oprócz konieczności uproszczeń, może być także fakt, że niekiedy sposób głosowania 
jest dziełem przypadku, a także iż często odrębne zdanie mają posłowie, którzy niedługo potem opuszczają dane ugrupowanie. Do badania poziomu aktywności ugrupowań opozycji parlamentarnej można dodatkowo zastosować także inne wskaźniki, np. liczbę wniesionych projektów ustaw, wniosków o odrzucenie projektu w całości, wniosków o wotum nieufności, interpelacji itd.

Sporym problemem jest rozbieżność między wartościami branych pod uwagę zmiennych. Jako przykład można podać, że w VI kadencji Sejmu mieliśmy do czynienia w 70,8\% z jednomyślnymi głosowaniami wszystkich ugrupowań parlamentarnych ${ }^{25}$, a jednocześnie z radykalnie opozycyjnymi i często agresywnymi wypowiedziami (szczególnie ze strony posłów PiS). W sferze werbalnej ugrupowania opozycyjne mogą, przede wszystkim na użytek elektoratu, podkreślać swoją radykalną i nieprzejednaną postawę wobec rządzących, podczas gdy przy rozpatrywaniu wielu kwestii merytorycznych ich założenia programowe są zbliżone do ugrupowań rządzących. Ponadto różnić mogą się działania podejmowane na forum parlamentarnym oraz poza parlamentem, gdy ich areną jest najczęściej ulica, a które z reguły mają bardziej radykalny charakter. Problem niespójności podejmowanych działań jest trudny do przezwyciężenia, a próba jego rozwiązania prowadzi do wniosku, że oprócz zastosowania wskaźników ilościowych konieczna wydaje się analiza o charakterze jakościowym.

Jeśli chodzi o ugrupowania pozaparlamentarne, to wydaje się, że podobnie można potraktować zarówno te, które określiły się jako partie polityczne, jak i organizacje mające inny status. W ich przypadku nasuwają się trzy wskaźniki: wypowiedzi, manifestacje i inne działania o charakterze antyrządowym oraz powiązania koalicyjne. Wypowiedzi mogą mieć charakter programowy ( $w$ badaniach należy uwzględnić stopień radykalizmu proponowanych zmian w stosunku do istniejącego systemu i założeń programowych ugrupowań rządzących) oraz doraźny (takie wypowiedzi zawierają najczęściej krytykę bieżącej polityki rządu i również można stwierdzić jej natężenie), ale samodzielnie nie stanowią miarodajnego wskaźnika. Wynika to z faktu, że w imieniu ugrupowań niemających szans na udział we władzy czy niedążących do tego, a tym samym nieponoszących żadnej odpowiedzialności politycznej, powiedzieć można praktycznie wszystko, a problem upublicznienia wypowiedzi w zasadzie nie występuje. Zatem wypowiedzi należy uwzględniać jedynie łącznie z innymi wskaźnikami - częstotliwością organizowania różnego rodzaju akcji protestacyjnych (z uwzględnieniem ich zasięgu) czy uczestniczenia w nich lub/i rodzajem ugrupowań, z którymi zawierane są porozumienia i koalicje. Szczególnie dotyczy to związków z partiami opozycji parlamentarnej, gdyż powiązanie takie oznacza najczęściej równy lub wyższy poziom radykalizmu. Podobnie jak w odniesieniu do zagadnień poruszanych poprzednio analizom ilościowym muszą towarzyszyć jakościowe, co podważa możliwość stworzenia jakiejś w miarę precyzyjnej skali opozycyjności.

25 K. Łabędź, Opozycja parlamentarna w Polsce - dwoistośćfunkcji, [w:] Problemy demokracji, red. M. Lakomy, M. Nowina Konopka, Kraków 2014, s. 21. 


\section{TRUDNOŚCI Z TYPOLOGIZACJĄ OPOZYCJI POLITYCZNEJ}

Istnienie wspomnianej wyżej niespójności działań podejmowanych przez poszczególne ugrupowania opozycyjne powoduje również trudności w zakwalifikowaniu ich do różnych typów w ramach istniejących typologii opozycji. Najistotniejszą z nich z punktu widzenia systemu demokratycznego wydaje się podział ze względu na stosunek do podstawowych zasad, wartości i instytucji systemu politycznego na opozycję prosystemową (niekwestionującą tych elementów) i antysystemową (dążącą do ich zmiany). Co prawda, nie występują w Polsce partie antysystemowe, niemniej jednak w rzeczywistości mamy do czynienia z pewnymi zachowaniami mającymi taki charakter. Wśród działań, które można uznać za przejawy podważania legitymizacji demokratycznego systemu politycznego w istniejącej postaci (demokracji liberalnej), można przykładowo wymienić wzywanie do łamania prawa i zachowania naruszające prawo, wzywanie do nienawiści wobec różnego typu mniejszości i do ograniczania ich praw, zawieszanie udziału w debatach parlamentarnych, wypowiedzi stwierdzające, że istniejący system jest niedemokratyczny, a wybory są fałszowane itp.

Problem zaliczenia poszczególnych ugrupowań do jednego z wymienionych typów opozycji dobrze charakteryzują słowa Juana J. Linza, który rozróżnił opozycję lojalną, półlojalną i nielojalną (co można uznać za typologię podobną do wyżej przytoczonej) i stwierdził, że: Opozycje lojalna od nielojalności odróżniają zatem wytacznie: umiar, względna kultura polityczna i unikanie jawnych nadużyćw stosowaniu owych chwytów [ataków na cały system, systematycznego szkalowania legalnie działających przeciwników, paraliżowania prac parlamentu i innych - K.E.]. Opozycja nielojalna zwykle portretuje przeciwników jako agentów tajemniczych i zakonspirowanych obcych sit: komunistów, masonów, światowego kapitatu, Watykanu czy wrogiego mocarstwa ${ }^{26}$. Wynika z tego, że rozróżnienie typów opozycji ze względu na stosunek do istniejącego systemu ma charakter płynny i nieostry, a poszczególne ugrupowania mogą przejawiać cechy różnych typów.

Podobnie jest w przypadku innych podziałów, $\mathrm{z}$ których istotnego aspektu funkcjonowania opozycji dotyczy typologia skonstruowana w oparciu o kryterium relacji pomiędzy ugrupowaniami opozycyjnymi a tworzącymi rząd, obejmująca opozycję konfrontacyjną, czyli odmawiającą jakiegokolwiek współdziałania z rządem, oraz opozycję kooperacyjną, podejmującą takie współdziałanie i wspierającą rząd w części działań27. Co prawda, pierwsza z nich jest charakterystyczna przede wszystkim dla westminsterskiego modelu demokracji, a w Polsce, podobnie jak w większości krajów europejskich, mamy do czynienia $\mathrm{z}$ opozycją drugiego typu, jednak typologia ta zwraca uwagę na dwie możliwości zachowania się opozycji, o których przewadze można mówić w poszczególnych przypadkach.

Podobne przesłanki legły u podstaw jeszcze innych podziałów opozycji, m.in. typologii mówiącej o opozycji typu nordyckiego i typu łacińskiego. Pierwszy z nich

$\begin{array}{ll}26 & \text { J.J. Linz, Kryzys, zatamanie..., s. } 42 . \\ 27 & \text { T. Krawczyk, Opozycja polityczna..., s. } 145 .\end{array}$ 
obejmuje ugrupowania opozycyjne gotowe do szerokiego kompromisu z rządem, motywowanego dobrem państwa. Używając innych określeń, które wydają się mieć zbliżone znaczenie, jest to opozycja umiarkowana (konstruktywna, wywierająca wpływ na politykę państwa) czy odpowiedzialna. Drugi typ tworzą ugrupowania pozostające $\mathrm{w}$ konflikcie z rządem w sprawach fundamentalnych, które kierując się własnymi interesami, są niezdolne do zawierania z rządem kompromisów (w tym znaczeniu jest to opozycja nieodpowiedzialna, a można ją określić także jako radykalną) ${ }^{28}$. Podsumowując: poszczególne ugrupowania opozycyjne, choć z różnym natężeniem, posiadają cechy różnych typów opozycji, co uniemożliwia ich jednoznaczne zaklasyfikowanie.

Bardzo ważnym podziałem, dokonanym ze względu na stopień spójności opozycji, jest rozróżnienie opozycji zintegrowanej i sfragmentaryzowanej ${ }^{29}$. Od stopnia spójności opozycji zależy zdolność do wspólnych wystąpień czy uzgodnienia różnych działań, a zatem siła, z jaką opozycja może wywierać wpływ na ugrupowania rządzące. Mówiąc inaczej, stopień integracji opozycji jest jednym z czynników determinujących sposób jej traktowania przez rządzących ${ }^{30}$. Zgodnie z zastosowaną tu koncepcją miarą poziomu integracji opozycji politycznej są dwie zmienne - zakres konsensusu normatywnego oraz stopień strukturalnej integracji. Zakres zgody co do podstawowych wartości i procedur systemu można określić w oparciu o wypowiedzi i inne działania, a o stosunkach o charakterze formalnym znaleźć informacje w oficjalnych źródłach. Natomiast istotną trudnością jest najczęściej wnioskowanie o istnieniu, charakterze i przebiegu stosunków nieformalnych pomiędzy przedstawicielami poszczególnych ugrupowań (a nawet różnych frakcji tego samego ugrupowania) ${ }^{31}$, gdyż wymagałoby to trudnej do zastosowania w praktyce obserwacji (najlepiej uczestniczącej). Trzeba oczywiście pamiętać, że w rzeczywistości nigdy nie będziemy mieli do czynienia z opozycją w pełni zintegrowaną (występuje bowiem zawsze element rywalizacji) ani z całkowicie sfragmentaryzowaną (zawsze istnieją jakieś wspólne interesy).

\section{ZAKOŃCZENIE}

Jedną z największych trudności, leżącą u podstaw wielu wymienionych poprzednio, jest praktyczna niemożność dotarcia do rzeczywistych motywacji działających osób i znaczeń przypisywanych przez nie różnym przedmiotom (co dotyczy badania polityki, a szerzej stosunków społecznych w ogóle). Stwierdzenie to wynika z przekonania, że w badaniach opozycji politycznej konieczne jest stosowanie różnych perspektyw

28 Tamże, s. 153.

29 Jest to rozróżnienie wykorzystujące typologię elit politycznych przedstawioną przez Johna Higleya i współpracowników w koncepcji określanej jako neofunkcjonalny paradygmat elitystyczny. Zob. M. Żyromski, Teorie elit a systemy polityczne, Poznań 2007, rozdz. X.

30 Szerzej problematykę typologii opozycji omówiłem w: Opozycja parlamentarna w Polsce $w$ latach 1997-2010, red. K. Łabędź, Kraków 2012, s. 12-15.

31 Co w polityce, jak wskazuje chociażby „afera podsłuchowa”, ma istotne znaczenie. 
badawczych, w tym dwóch mających charakter komplementarny - behawioralnej i interpretacjonistycznej. Chcąc dowiedzieć się, jakie znaczenie dany aktor przypisuje podejmowanym przez siebie zachowaniom, w dodatku zakładając, że to samo zachowanie może wyrażać różne znaczenie w zmieniającym się kontekście sytuacyjnym (i odwrotnie - $\mathrm{z}$ odmiennymi zachowaniami może wiązać się to samo znaczenie), należałoby zastosować takie techniki jak np. pogłębiony wywiad. W przypadku polityków, podejmujących w części działania, których rzeczywiste cele (czyli wskazanie motywu „po co?”) muszą być i są na ogół ukryte, podobnie jak rzeczywiste powody ich podjęcia (czyli wskazanie motywu „z jakiego powodu?”), nie wystarczy odwołanie się do „typowych motywów", o których pisał Alfred Schutz. Należałoby więc prowadzić badania wykorzystujące łącznie wiele metod i technik, w tym np. eksperyment czy dokumenty osobiste. Jest to jednak postępowanie energochłonne, nastręczające sporo praktycznych trudności (przede wszystkim jeśli chodzi o dostępność polityków), a w dodatku niegwarantujące dotarcia do faktycznych motywacji (dla wyobrażenia sobie tych trudności można postawić się w sytuacji badacza, który pyta Antoniego Macierewicza, czy wierzy w zamach smoleński).

Powyżej wskazane zostały przede wszystkim liczne trudności wiążące się z badaniem istniejącej w Polsce opozycji politycznej. Przytoczone argumenty wskazują, że raczej niemożliwe jest opracowanie jednego narzędzia służącego badaniu opozycji, które jednocześnie byłoby precyzyjne i rzetelne oraz w wystarczającym stopniu wystandaryzowane i syntetyczne. Ze względu na złożoność przedmiotu badań, chcąc uwzględnić możliwie wiele aspektów funkcjonowania opozycji, konieczne jest zastosowanie analiz ilościowych i jakościowych oraz różnych perspektyw badawczych.

\section{BIBLIOGRAFIA}

Bożyk S., Prawnoustrojowy status opozycji parlamentarnej w Sejmie Rzeczypospolitej Polskiej, Bialystok 2006.

„Bunt stadionów” zachęta, by rząd Donalda Tuska obalili kibole? Politolog: Sam sobie zgotowat ten los, naTemat, 23 IV 2013, [online] http://natemat.pl/59423,bunt-stadionow-zacheta-by-rzad-donalda-tuska-obalili-kibole-politolog-sam-sobie-zgotowal-ten-los.

A Dictionary of the Social Sciences, red. J. Gould, W.I. Kolb, New York 1964.

„Dla Was nie będzie gwizdów, będą szubienice". Kibole Legii Warszawa zapowiadaja wymordowanie KOD, opozycji imediów, naTemat, 8 V 2016, [online] http://natemat.pl/179271,dla-was-nie-bedzie-gwizdow-beda-szubienice-kibole-legii-warszawa-zapowiadaja-wymordowanie-kod-opozycji-i-mediow.

Głowacki W., Opozycja, o której marzy każdy rzad. KOD, PO i Nowoczesna mobilizuja już zmobilizowanych, „Dziennik Polska” 2016, 6 V, [online] http://www.polskatimes.pl/fakty/polityka/a/opozycja-o-ktorej-marzy-kazdy-rzad-kod-po-i-nowoczesna-mobilizuja-juz-zmobilizowanych-analiza,9960410/.

Krawczyk T., Opozycja polityczna w państwach demokratycznych, [w:] Studia z teorii polityki, t. 3, red. A. Czajowski, L. Sobkowiak, Wrocław 2000. 
Linz J.J., Kryzys, zatamanie i powrót do równowagi, [w:] Wtadza i spoteczeństwo 2. Antologia tekstów z zakresu socjologii polityki, wybór i oprac. J. Szczupaczyński, Warszawa 1998.

Łabędź K., Opozycja parlamentarna w Polsce - dwoistość funkcji, [w:] Problemy demokracji, red. M. Lakomy, M. Nowina Konopka, Kraków 2014.

Łabędź K., Znaczenie pojęcia „opozycja polityczna” w odniesieniu do Polski lat osiemdziesiątych, [w:] Historia, polityka, spoteczeństwo. Ksiega jubileuszowa dedykowana Profesorowi Henrykowi Cimkowi, red. W. Bonusiak i in., Rzeszów 2008.

Machelski Z., Opozycja w systemie demokracji parlamentarnej. Wielka Brytania, Niemcy, Wtochy, Warszawa 2001.

Opozycja parlamentarna, red. E. Zwierzchowski, Warszawa 2000.

Opozycja parlamentarna w Polsce w latach 1997-2010, red. K. Łabędź, Kraków 2012.

Opozycja polityczna, [w:] Encyklopedia politologii, t. 1: Teoria polityki, red. W. Sokół, M. Żmigrodzki, Kraków 1999.

Opozycja polityczna, [w:] Leksykon politologii, red. A. Antoszewski, R. Herbut, Wrocław 1995.

Oświadczenie Grupy Uderzeniowej, [online] www.oburzeni.org.pl.

Pałecki K., Opozycja polityczna - próba typologii, [w:] Opozycja w systemach demokratycznych i niedemokratycznych, red. K. Łabędź, M. Mikołajczyk, Kraków 2001.

Plankton polityczny, Wikipedia, [online] https://pl.wikipedia.org/wiki/Plankton_polityczny.

PLANKTON POLITYCZNY - Blog polityczny o planktonie politycznym, [online] planktonpolityczny.blox.pl.

Political Oppositions in Western Democracies, red. R.A. Dahl, New Haven 1966.

Porozumienie-organizacji, [online] pressmix.eu.

Sartori G., Teoria demokracji, przeł. P. Amsterdamski, D. Grinberg, Warszawa 1998.

Wybrane aspekty funkcjonowania Sejmu w latach 1997-2007, red. J. Sokołowski, P. Poznański,

Kraków 2008.

Wykaz partii wpisanych do ewidencji partii politycznych, PKW, [online] http://pkw.gov.pl/322_

Wykaz_partii_politycznych/1/404_WYKAZ_PARTII_WPISANYCH_DO_EWI-

DENCJI_PARTII_POLITYCZNYCH.

Żyromski M., Teorie elit a systemy polityczne, Poznań 2007.

Dr hab. Krzysztof ŁABĘDŹ - prof. nadzw. w Akademii Ignatianum w Krakowie, jego zainteresowania naukowe obejmują socjologię polityki, funkcjonowanie polskiego systemu politycznego, najnowszą historię Polski. 